\title{
(Re)inscribing Blackness onto the Canadian Soil: Memory and Resistance in Contemporary African-Canadian Drama
}

\begin{abstract}
Since black Canadians constitute only approximately two percent of Canada's population, blackness is not considered natural to Canada. As a result of this, and due to the racism of the dominant white society, black belonging is always under threat of erasure. This paper focuses on two contemporary African-Canadian plays, Djanet Sears's The Adventures of a Black Girl in Search of God (2001) and Lorena Gale's Je me souviens: Memories of an Expatriate Anglophone Montréalaise Québecoise Exiled in Canada (2001), and attempts to demonstrate how the themes of remembering and resistance to forgetfulness make them political plays. It argues that by reclaiming forgotten segments of Canadian history and remembering moments of racism, they not only go against the grain of Canada's dominant history and cast a shadow of doubt over the seemingly untarnished image of Canada in the world but also recreate a space for blackness in the Canadian national narrative.
\end{abstract}

Key words

Djanet Sears; Lorena Gale; Canadian drama; blackness; national narrative

In August 1995 the Holland Township Council decided to rename Negro Creek Road to Moggie Road, claiming that the word 'Negro' had become problematic. South of the Canadian border it is definitely perceived as a slur. However, as Lawrence Hill, an African-Canadian author, points out in his article in The Guardian entitled "Why I'm Not Allowed My Book Title," where he explains what stood behind his American publisher's decision to change the title of his book The Book of Negroes, the word 'Negro' "resonates differently in Canada." 
While in the USA, when using it, "you are asking to have your nose broken," in Canada "you are probably just indicating publicly that you are out of touch with how people speak these days" (Hill 2008). Despite this, in an attempt at political correctness, the Holland Township passed a bylaw that was to rename Negro Creek Road after a 19th-century white settler named George Moggie. The local black community immediately interpreted this as a deliberate attempt at "eradicating any trace of the almost two centuries of black habitation of the area" (Sanders 2003: 119) and fought to reverse the council's controversial decision. This incident not only inspired the African-Canadian playwright Djanet Sears to write her play The Adventures of a Black Girl in Search of God but also speaks volumes about the general tendency of Canadians to exclude their black countrymen from their national narrative (Sanders 2003: 119).

Although African Canadians have lived in Canada for centuries, blackness is not perceived as part of Canadian national identity. Being Canadian is synonymous with being white (cf. Mukherjee 1999). If one does not look convincingly white, Canadians tend to inquire about one's origins, automatically assuming that one must be from another country, an immigrant, or simply an Other. This questioning is hardly ever an act of innocent curiosity. As some authors demonstrate, by asking about a person's ethnic origin, the inquirer usually unintentionally reveals his deeply held racial prejudice (cf. Mukherjee 1999; Hill 2002). Lorena Gale, a Montreal-born actress and playwright, touches upon this issue in her autobiographical extended monologue play Je me souviens: Memories of an Expatriate Anglophone Montréalaise Québecoise Exiled in Canada (2011; first published in 2001): "When people ask me which island I come from, I say Montreal. And they look confused. When people tell me to go back where I came from-I look confused" (96). Gale's text indicates that blackness is perceived as unnatural to Canada, as if a person of darker complexion could not possibly be born there. In addition, black Canadians are almost uniformly considered recent arrivals from the Caribbean, hence the question which island they come from. Although it is true that Caribbean Canadians constitute the largest group of Canada's black population, making solely post-war black immigrants from the Caribbean representative of Canadian blackness entails obliterating the almost five hundred years' presence of blacks in Canada.

A national narrative always arises from a dialectics of remembering and forgetting. What is to be remembered is not selected in a politically neutral and objective fashion. Malcolm Ashmore and Steven D. Brown (2009) confirm this. According to them, remembering is always inherently political because it is motivated by a certain purpose and is a product of interaction between "active agents," in which such factors as accountability, responsibility, struggles, power and domination come into play (17). The purpose is usually to shape a nation's sustaining vision of itself. Canada identifies itself as a "peaceable kingdom," a notion derived from an eponymous painting by Edward Hicks depicting "an illustration of Isaiah's prophecy of harmony in nature and among nations" (Kilbourn 1989: 28). The core of this idea is that Canada differs from other countries in its low 
levels of violence, greater respect for the law and its tolerance of other groups. In particular, this myth is aimed at distinguishing Canada from the USA and establishing its moral superiority over the neighbor to the south. Once the majority of a country's citizens identify themselves with such a popular narrative, it becomes difficult to alter. The narrative then permits remembering only stories that confirm it and requires overlooking or silencing those that narrate alternative pasts.

This is the reason why pretending that Canada has a blackless past is so convenient. It exonerates the nation from difficult histories (for example, the history of slavery) and sustains its safe-haven myth. Any attempt at reclaiming forgotten segments of Canadian history, or providing a counter-history to the official version of history, is then inevitably regarded as subversive. I argue that since Djanet Sears's The Adventures of a Black Girl in Search of God and Lorena Gale's Je me souviens are both preoccupied with memory and remembering, be it communal or personal, and compel a re-immersion in stories that Canadians would rather rewrite to their advantage, they can be read as political acts. Although from the outside it may seem that remembering traumatic experiences, especially if done in excess, can be paralyzing and an impediment to progress, Sears and Gale present the act of remembering as something which is individually and communally curative. The narrativization of subjugated traumatic memories requires a degree of agency (Ruti 2015: 51), which helps a member of a marginalized group achieve subjectivity. Remembering is thus essential for the identity construction of marginalized minorities, either at a personal or a communal level. Through describing their experiences in their own terms and publicly, they gain a self-defined self and make themselves "the kind of people who can make knowledge and history" (Roof and Wiegman 1995: 130). This constitutes a politically laden act because they insert themselves into language, history and culture as "legitimate speakers and historical agents" (Roof and Wiegman 1995: 128) - roles that were reserved only for members of dominant groups in the past.

\section{Recovering previously silenced histories}

That Sears's play The Adventures of a Black Girl in Search of God was intended as a political statement is evident from its production history. It premiered at Harbour Front Centre in 2002 as a co-production by Nightwood Theatre and the debuting Obsidian Theatre Company. Both are based in Toronto and are associated with Canadian political theatre, the former being Canada's oldest feminist theatre and the latter specializing in black Canadian issues. The political nature of Sears's project was further underlined by the program that was distributed during the premiere (Petropolous 2008: 75). It reminded the audience that the production of the play was part of Black History Month, instituted to remember and honour the contributions of black Canadians to Canada's history, culture and heritage, and that the production had been supported from government funds intended for this purpose. In line with the mission of Black History Month, the 
program included an extensive account of "the history of the people who settled Grey County, an area just north of Toronto, following the War of 1812" (Petropolous 2008: 75), an almost forgotten piece of history which serves as the backdrop to Sears's politically engaged play.

Although its title makes a reference to George Bernard Shaw's short story The Adventures of the Black Girl in Her Search for God (2007; first published in 1932), a satirical allegory relating the experiences of a South African black girl who goes into the wilderness searching for God, Sears's play The Adventures of a Black Girl in Search of God is not an adaptation of it. As the playwright has said in an interview, it is actually her "re-visioning" of Shaw's story (Bunton 2004). She gives voice to a black female perspective, which, as she seems to infer, is absent from Shaw's story although its title clearly makes the black girl the protagonist. Sears, however, employs different characters and a different context to tell a story of loss and a search for meaning. While Shaw's black girl is a fresh convert who, intrigued by some inconsistencies in her newly acquired religion, attempts to find and speak to God, Sears's black girl is an obstetrician-turned-academic named Rainey, who is mourning the loss of her young daughter to meningitis, which she had failed to diagnose early enough to save her life. Sears portrays Rainey going through a severe crisis of faith and questioning of God.

Despite this, The Adventures of a Black Girl in Search of God is not just a dramatization of personal loss and a subsequent search for spiritual healing. Rainey's crisis of faith is broader and goes beyond her personal tragedy. At one point she evokes the lynching scene of the Texan James Byrd:

God has allowed the most vicious atrocities.... When that man Byrd, James Byrd, was dragged by a chain, from the back of a pickup truck, conscious to the last, feeling his limbs crumble, separate from his body, one by oneWHAT DO YOU SUSPECT GOD WAS THINKING? "Well, this is all part of my plan. I sure hope they learn something from this down here." What do you suspect the man learned as his arms fell away behind him?

(Sears 2003: 32)

As can be seen, Rainey's questioning of God is also tied to the wrongs and injustices suffered by people of African descent in North America, Canada not excluded. Memories of these are an integral part of the fabric of Sears's play.

Her father Abendigo Johnson, who has been fortunate enough to have worked his way up to become a judge, remembers that when he moved from the United States to Canada, the country was not the Canaan Land that it had appeared as in the popular consciousness of American blacks for more than a century. $\mathrm{He}$ recalls several incidents that counter the popular image of Canada as a racismfree country. He retrieves the memory of "black tourists making pilgrimages to Josiah Henson's grave" in Dresden, Ontario, who "would not be served in the restaurants [there]" (Sears 2003: 44). Sears makes a direct reference to segregation practices in a town that was one of the terminuses of the Underground Rail- 
road and served as "a beacon of hope and freedom" for African-American slave refugees in the 19th century (Décoste 2013). Although Canada is hardly ever mentioned in connection with racial segregation, and it is often implied that there was no segregation in Canada at the time when it was a common practice south of the border, the 30-minute National Film Board documentary entitled Dresden Story (1954) proves the opposite. Despite the fact that discrimination in public places "on grounds of race, creed, color, nationality, ancestry or place of origin" was outlawed by the Fair Accommodation Practices Act in 1954, the film shows that some establishments in the town continued to exclude black people long after the law had taken effect.

Abendigo also recollects what he was told upon retirement by one of the friends he made during his time as the judge: "You're not like other blacks. You're a very special Black" (Sears 2003: 44). What was meant as a compliment is understood by Abendigo as a sign of his friend's deeply embedded racial prejudice and, in a way, a sign of his own failure: "After all those years of trying, of setting an example, of trying to make them understand that we [black people] are as good and as bad as everyone else, I realized that all of it was for nothing. I was an anomaly to him. A freak. A talking monkey" (Sears 2003: 44). In his friend's opinion, the rule is that blacks possess a mentality that prevents them from becoming successful or rich, and Abendigo's success is only an exception to the rule.

Abendigo's personal memories, although unique and distinct in nature, might be viewed as representative of the experience of many people of African descent in Canada. His is not an individual's story but a communal utterance. After all, individual memory is often intertwined with, and in part also shaped by, collective or social memory: "one does not remember alone but with the help of memories of others and of shared cultural codes" (qtd. in McLaughlin 2010: 50). When read against the majority's cultural memories, Abendigo's personal memories additionally point to the silences and selectiveness of the former.

Sears's play addresses and protests against the majority's cultural memories and, as Sharon Morgan Beckford (2008) argues, the erasure of black Canadians "from the Canadian physical and imaginary geographic landscapes" (472). The playwright's description of the setting at the very beginning of the play goes against the grain of dominant historiography and firmly inscribes, or re-inscribes, the presence of blacks in the Canadian landscape:

Nestled quietly at the base of the peninsula which cleaves the waters of Georgian Bay and Lake Huron, there lives a small and little known enclave of the descendants of African soldiers. During the War of 1812, Captain Runchy's Company of Coloured Men, a military unit of African soldiers, made up of free men and escaped slaves, distinguished themselves in major battles against the invading United States army. Following the war, Sir Peregrine Maitland, Lieutenant-Governor of Upper Canada, offered Black veterans grants of the lush and fertile farmland in what was to become Negro Creek. (Sears 2003: 2) 
This opening renders the Negro Creek community as one of the oldest black settlements in Canada and their property rights to land as defining their citizenship and belonging.

Sears insists that her characters belong to the land, and the land belongs to them. They can trace their ancestry back to the African soldiers who were deeded land in the area of today's Negro Creek for having fought on the side of the British in the War of 1812. The characters of the play were born and raised on the land, and their identity is enmeshed in it. Sears reinforces the significance of land to her people by quoting an epigram from Aned Kgositsle's Part of Each Other, Part of the Earth: "We, Africans in America, come from a people tied to the Earth, people of the drums which echo the Earth's heartbeat. ... People tied to soil and wind and rain as to each other..." (qtd. in Sears 2003: 3). She also employs the theatrical device of a chorus to do so. Composed of the souls of the characters' ancestors, the chorus rises out of the land at the beginning of the play and represents it throughout the rest of it. The chorus members regroup on the stage to form different types of landscape, be it the woods or lush farmland, which lends additional force to the idea that people and the land are linked physically and spiritually. In addition, Sears has the protagonist Rainey eat morsels of earth, emphasizing that there is a source of healing in it. "I've been trying to get out of here all my life," says Rainey voicing her uprootedness, "and now, now I just hunger for the soft, sugary earth by Negro Creek. My Pa's family's lived and died on this bush land - been ours since the War of 1812. Maybe that's why it tastes so sweet" (Sears 2003: 19). I can only agree with Elizabeth Brown-Guillory (2006) that Rainey's appetite for earth is a reflection of her longing to return home (167). Eating earth not only reconnects her with her former community but also helps her reclaim her sense of self after the death of her beloved daughter.

The earth that Rainey savours is where the remains of her ancestors repose. They made sacrifices for this land, and Rainey's father Abendigo struggles for this not to be forgotten. This quest, which he undertakes shortly before his death "to ensure that his community's roots in Negro Creek remain intact" (BrownGuillory 2006: 166), is a parallel storyline to Rainey's story of healing and reconciliation. Abendigo organizes a secret mission to reclaim his great-great-grandfather Juma Moore's uniform from Toronto's Royal Ontario Museum. This piece of clothing is sacred to his family. His grandmother had drowned while giving it an annual ritual cleaning:

They'd go in the water [of Negro Creek] with it, hold it under, and let the creek purify it. Lorraine [Abendigo's grandmother] had done it for years, but this time. ... Well, she was in the water when it happened. The uniform slipped down, out of her hands and she went after it. ... They found her downstream when the creek thawed that spring, her hands still gripping that jacket. (Sears 2003: 19)

The authorities confiscated it, claiming that it was "the property of Her Majesty's 
army" (Sears 2003: 20). For Abendigo, "[i]t's part of the foundation of this land. It should be displayed with pride, not hidden away in a museum's storage trunk" (Sears 2003: 108). His reclamation of the uniform can be interpreted as a quest to prove his and his ancestors' claim to Canadian national identity.

With a similar intention in mind, his friends from the Lotsa Soap Cleaning Company, a slightly comical group of septuagenarians who have dedicated their later years to the "liberation" of racist icons and artifacts like "lawn ornaments, cookie jars, piggy banks, plaques, figurines, visual images and [other] ephemera" that often represent blackness in a dehumanizing way (Sears 2003: 41), rewrite the official historical records, which usually elide the presence of blacks in the early phases of nation-building. Girlene rewrites "the wording on a caption under a large portrait of John A. MacDonald's wife” (Sears 2003: 99) to release a skeleton from the nation's closet: the first Canadian prime minister's second wife was born in Jamaica and was of both European and African descent. Another of Abendigo's friends chooses the name of Olivier Le Jeune, "the first known black resident of Canada [from] 1628" (Sears 2003: 33), as a code name for the operation to save Juma Moore's uniform. These seemingly insignificant historical details are brought to the fore as irrefutable evidence that blacks had a presence in Canada when its territory was only just being settled by the ancestors of dominant groups and that they were also present when Canada was being constituted as an independent country.

It is not a coincidence that all these acts of subversive remembering occur at the moment when the name Negro Creek is threatened with erasure from the local and national register. It is clear that what Jacqueline Petropolous (2008) refers to as "[a] short-lived act of ideological erasure" (75) is just a minor episode in the history of oppression of African Canadians. By trying to retrieve from oblivion the moments that historically situate blacks in Canada, Djanet Sears effectively rewrites national history from an African-Canadian perspective and thus changes the view of her people, seeing them as subjects actively making history rather than being objects of it.

\section{Personal memory as resistance}

Remembering is also at the heart of Lorena Gale's drama Je me souviens as the translation of its title ('I remember') suggests. Found on every license plate in the province, this official motto of francophone Quebec allegedly refers to the protection of French-Canadian identity. It is an oath that the Quebeckers will never forget their ancient lineage, traditions or past.

Gale also swears to remember, never to forget. As she writes in "Going Home," a brief preface to the 2001 edition of her play, her text is "the articulation of personal memory as political resistance" (qtd. in Holoch 2011). She specifically identifies at whom her writing is directed. The play is "a scathing criticism of Mr. Parizeau" (qtd. in Holoch 2011), the premier of the province of Quebec at 
the time of the second referendum on Quebec's sovereignty. Parizeau is infamously remembered for blaming the razor-thin defeat of the 'yes' side in the 1995 referendum on "money and the ethnic vote." Commenting on the loss, he used "nous" (we) only in reference to Francophone Quebeckers ("Money and the ethnic vote"), excluding Anglophones and allophones from his definition of the Quebec nation. This deliberate act of omission provoked Gale to respond.

Although her monodrama speaks directly to Quebeckers, it was never performed in the province. Premiered at Eastern Front Theatre in Halifax in 1998, it was subsequently produced for theatres in Calgary, Vancouver and Victoria. However, not once did Gale present it on a stage in Quebec despite the fact that her one-woman show takes her love-hate relationship with the province as its subject matter and fiercely defends her right as an Anglophone black woman to call herself a Quebecker.

Having been born and raised in the Little Burgundy community of Montreal, Gale feels like a Quebecker despite the fact that as a black Anglophone she is not identified as one by others. Even the first scene of the play, set in Vancouver, where she is living, depicts her defending her right to her Quebecois identity. Meeting her old friend from Montreal in a café, her alter ego Lorena is silenced by a young white Quebecois who has overheard her critical comments on recent negative changes in her home province: "--Hey you! You don't say dat! You don't talk about Montréal!" (Gale 2011: 94). When she retorts that he should shut up and mind his own business, he insists that what she has to say about Quebec is his business: "Me. I'm from Montréal. You don't say nutting. Tu n'as pas le droit!" (Gale 2011: 94). The young Quebecois in fact denies her the right to speak, assuming that being black and speaking English, Lorena cannot be a Quebecker. What follows, in fact the play as a whole, is Gale's indignant backlash against such unduly limiting definitions of Quebec and, by extension, also of Canadian citizenship and identity.

Gale shows that she belongs by guiding her audience through her early memories, all attached to Montreal, the place she insists on calling her home. As she says in the preface, her memories are "mine. They make me who I am. They cannot be negated or denied. It doesn't matter what Parizeau or anybody thinks. Montreal was and always will be my home. I have a living history to prove it" (qtd. in Holoch 2011). The audience watch her anecdotal memories play out against the backdrop of a black-and-white slide show. The slides, which often feature images of Montreal, create a sense of photo-album nostalgia and visually reinforce Gale's strong statements. Her personal memories are meant to unequivocally prove her belonging to Quebec. On the other hand, they are also supposed to illustrate how the lives of individuals can be negatively affected by overly narrow and restrictive notions of Quebec identity.

For this purpose, Gale revisits her younger self and recalls what Bina Toledo Freiwald (2002) terms "an originary scene of racial interpellation" (44), the moment when a black child becomes aware of her racial difference. As Gale demonstrates, this awareness usually arises from the discrepancy between the ways one sees one- 
self and is seen by others. In a geography lesson at elementary school, Lorena has several stereotypes projected onto herself by one of her teachers. Showing "a turnof-the-century depiction of a tribal Africa" to her class, Miss Bennett remarks:

Bunga of the Jungle. The jungle is a rain forest located in the Belgian Congo. The heart of deepest, darkest Africa. Can anybody tell us about Africa? Lorena?

Silence.

Bunga is an African. Africans are little primitive peoples with black skinLorena. And tight woolly hair-Lorena. And broad flat noses, who run about the jungle naked, climbing trees for fruit... (Gale 2011: 101-2)

On the basis of the colour of her skin, Lorena is grouped together with the imaginary Africans who often feature in the Western consciousness as "the missing link between man and ape" (Gates 1989:26) and are thus not only somatically but also culturally black, i.e. primitive and culturally inferior by European standards (cf. Foster 2008: 95).

Lorena seeks consolation and belonging with people of her colour, yet she is not successful there either. Black immigrants from the Caribbean share her African ancestry but regard her as 'too white' and 'too assimilated' to belong:

You know what da problem is wit you Canajun Blacks? You don't know where you come from. Ya don know who y'are. Ya talk like Whitey. ... You let the White man into your head and now you all messed up. You don tink straight. You Black on de outside, White on the inside. ... Assimilated Negroes. Dat's what you are. (Gale 2011: 96)

When Lorena's family moves from Little Burgundy to Outremont, a neighbourhood inhabited by immigrants, even though they believe they are, to use the words of Adele Holoch (2011), "more authentically Quebecois" than their neighbours, they are once again regarded as alien and sent back 'to where they came from', this time "in different languages" (Gale 2011: 97). Lorena the child is ostracized by her schoolmates: they "walk in packs behind [her], chanting: "niggerblack, niggerblack, niggerblack,' on the way to school" (Gale 2011: 101). Although she tries hard, Lorena does not belong. Gale explains:

It's a legacy of the African diaspora to become rooted to a land where one is seen as the "other". By virtue of my race alone I am immediately perceived as unnatural to my surroundings. Wherever I go in Canada there is a constant demand to explain, to justify, and defend my presence. It is as if race is exclusive of nationality; as if the criteria by which we define and measure what is Canadian or Quebecoise could not simply apply to me.

(qtd. in Cuder-Domínguez 2009: 354) 
Despite this, Lorena longs for belonging and tries hard to fit in, dancing Scottish, Israeli, Greek and Chinese dances on Canada's Multicultural Day (Gale 2011: 105). When she grows up, in an "attempt to merge into white Quebec," she starts a relationship with a white Francophone Quebecois (Cuder-Domínguez 2009: 359) - much to the frustration of her Anglophone friends and, at some moments, her own. The relationship only makes Lorena more intensely aware of the fact that she is part of more than one minority. In addition to being discriminated against or excluded on the basis of her race, as an Anglophone she also faces linguistic exclusion. Although her boyfriend's parents seem to be warmly accepting of her, struggling with their fractured English to make her feel at ease, his friends exclude and ridicule her by arrogantly using their rapid French in her presence.

However, their relationship is doomed to failure also for another reason. Lorena feels that Marcel refuses to see her for who she is, just as he refuses to recognize the subtle ways "in which society racializes black people" (Cuder-Domínguez 2009: 359). When they leave Montreal - and Lorena admits that "the farther from Montreal we travel the more conspicuous I feel" - and she becomes the object of the racialized gaze, Marcel pretends, or maybe rather chooses, not to see the "surprise in the faces of diners in the Casse Croute in Saint-Hyacinthe where we stop for lunch. Some sneak a peek at me between bites of hamburger steak and others gawk openly like I'm some strange and shameful beast. He is oblivious to my discomfort" (Gale 2011: 108). Marcel is voluntarily colorblind, admitting that when he looks at her, he can only see her: "I don't see no color. Just Loren" (Gale 2011: 110). His colorblind attitude makes Lorena sometimes forget who she is. However, as Ivan Lacko (2013) writes, one cannot transcend one's racial identity, nor can one deny or efface it.

As a result, Lorena is trying to detach herself from the stigma of blackness only to revert to it again a moment later. The cover of a book showing "the charred remains of a lynched Black man" surrounded by the Ku Klux Klan reminds her rather painfully about who she really is, and that the category of race cannot be eluded. She understands that her color is an integral part of her being: "Who I am is embedded in every cell of my skin," and concludes that if Marcel cannot see it, he cannot see her in her wholeness - "How can he love what he can't see?" (Gale 2011: 110).

This gradual identity construction of Lorena's, which culminates in her embracing both her black and Quebec identities, is best illustrated by a dream sequence written in French, which Pilar Cuder-Domínguez (2009) calls a "reverie" (356). In the dream Lorena is alone, lost in snow and blinded by a white glare. Although at first she seems to be paralyzed by fear, she finds the courage to begin to walk. As she walks, she glimpses another person in the distance, and approaching her, she realizes that person is herself. Seeing herself as an inseparable part of the snowy landscape, she dares to claim this space as her own. The "reverie" concludes with Gale's persona stating, "Et je me reveille" (Gale 2011: 125), or "I awake" in English translation. This may mean that she awakes to a new consciousness in which her personal history and identity as a Quebecker are an integral part of her being. 
The final scene starts with Lorena stating, "On October 30, 1995, I felt as if I'd come dangerously close to being severed from my personal and family histories" (Gale 2011: 125). It was then that Premier Parizeau pointed a blaming finger at Anglophone and immigrant Quebeckers for depriving the Québécois people of what he thought they had the right to - their own sovereign and independent state. This provoked in Quebeckers like Lorena feelings of exclusion from the national community. However, Lorena defiantly declares that her memories make her part of the community whether Parizeau and his sort like it or not, and they cannot be taken away from her or "legislated out of being," just as she cannot forfeit "the right to love Quebec, to speak to that love, or to vote for it" (Gale 2011: 126), which, as Holoch (2011) claims, is itself "a profound political statement a powerful rebuke to those who have questioned Gale's right to identify herself as Québécois." Gale does not just speak for herself. She speaks on behalf of Quebec's other minorities whose voices are often drowned out by the province's separatist rhetoric.

\section{Conclusion}

In the sixth scene of Gale's Je me souviens, Lorena the girl is told by Mr Camille, a Holocaust survivor, that "it's important that you remember" (99). He explains that if certain things are forgotten, they will repeat themselves. Gale's remembering, just like Sears's, can thus be understood as a defensive action. By rewriting official history and openly speaking about incidents of racism that they have experienced (although racism of the covert type that Jana Javorčíková (2005) refers to as "smiling discrimination"), they resist the erasure of specific cultural perspectives from the narrative of the Canadian nation and what Carol Talbot terms "the Great Denial" (qtd. in Freiwald 2002: 42): the lie that Canada has no problem with racism and, as a result, does not need to do anything about it. The memories that figure in Sears's and Gale's plays speak directly against this lie.

While Sears's drama seems to show more interest in reclaiming subjugated history, Gale's monodrama is a project seemingly more focused on personal memory. It, however, does not perceive it as being isolated from collective memory but rather as enmeshed within it. Despite an obvious difference in focus, both plays attempt to integrate uneasy memories into the Canadian collective memory and thereby expose how remembering can be used for political purposes.

Due to the tone of defiance that characterizes both plays, Sears's and Gale's memories might seem "combative" or "as if written in acid" (Clarke 271-272), but there is no anger in them. Gale objects to the stereotype of black writers being angry. She says that her main purpose in writing is to tell people what happened and the only thing she expects is acknowledgement on their part (Morrow 1999).

This does not mean that Sears's and Gale's plays rely on strictly rational persuasion. They are not political in the Brechtian sense. They do not expect the audience to emotionally 'estrange' themselves from what is happening on stage and 
perceive the performance, its context and meaning, only through the medium of reason (cf. Lacko 2011: 195). On the contrary, embracing the feminist ethos that 'the personal is political,' they combine the intellectual and the emotional in their poignant examinations of individual lives affected by racism and discrimination and demand their audiences take a stance.

\section{References}

Ashmore, Malcolm and Steven D. Brown (2009) “On Changing One's Mind Twice: The Strange Credibility of Retracting Recovered Memories”. In: Haaken, Jan and Paula Reavey (eds.) Memory Matters. Routledge, 17-40.

Beckford, Sharon Morgan (Jan., 2008) “"A Geography of the Mind': Black Canadian Women Writers as Cartographers of the Canadian Geographic Imagination”. Journal of Black Studies 38 (3): Blacks in Canada: Retrospects, Introspects,Prospects, 461-483.

Biggs, Julian, producer and director (1954) Dresden Story [documentary]. Canada: National Film Board.

Brown-Guillory, Elizabeth (2006) "Place and Displacement in Djanet Sears's Harlem Duet and The Adventures of a Black Girl in Search of God". In: Brown-Guillory, Elizabeth (ed.) Middle Passages and the Healing Place of History: Migration and Identity in Black Women's Literature. Columbus: The Ohio State University Press, 155-170.

Bunton, Mat (2004) An Interview with Djanet Sears. Canadian Adaptations of Shakespeare Project. Accessed on August 20, 2014. http://www.canadianshakespeares.ca/i_dsears. cfm

Clarke, George Elliott (2009) "Strategies for Legitimizing Difference. Mixed-Race Resistance in the Works of Andrea Thompson and Lorena Gale, Two African-Canadian Writers". In: Florby, Gunilla, Mark Shackleton and Katri Suhonen (eds.) Canada: Images of a Post/National Society. Brussels: P.I.E. Peter Lang S.A., 259-276.

Cuder-Domínguez, Pilar (2009) "Sharing Quebec. Lorena Gale's Je me souviens and George Elliott Clarke's Québécité”. In : Barthet, Stella Borg (ed.) Shared Waters: Soundings in Postcolonial Literatures. Amsterdam: Rodopi B.V., 346-375.

Décoste, Rachel (2013) “Canada's First Racial Discrimination Trial”. The Huffington Post, February 20, 2013. Accessed on September 15, 2014. http://www.huffingtonpost.ca/ rachel-decoste/ canadas-first-racial-disc_1_b_2721434.html

Freiwald, Bina Toledo (2002) "Identity, Community, and Nation in Black Canadian Women's Autobiography”. In: Schaub, Danielle and Christl Verduyn (eds.) Identity, Community, Nation: Essays on Canadian Writing. Jerusalem: The Hebrew University Magnes Press, 34-54.

Gale, Lorena (2011) "Je me souviens: Memories of an expatriate Anglophone, Montréalaise, Québécoise, exiled in Canada”. In: Knowles, Ric (ed.) Africa, Solo. Toronto: Playwrights Canada Press, 89-126. First published in 2001.

Gates, Henry Louis, Jr. (1989) Figures in Black: Words, Signs, and the "Racial” Self. New York: Oxford University Press.

Foster, Cecil (2008) Blackness and Modernity: The Colour of Humanity and the Quest for Freedom. Montreal: Mcgill Queens UP.

Hill, Lawrence (2002) Black Berry, Sweet Juice. Harper Perennial Canada.

Hill, Lawrence (2008) "Why I'm not allowed my book title". The Guardian, May 20, 2008. Accessed on September 5, 2010. http://www.theguardian.com/books/booksblog/ 2008/may/20/ whyimnotallowedmybooktit

Holoch, Adele (2011) "Memory and Resistance". Review of Je me souviens: Memories of an expatriate Anglophone Montréalaise Québécoise exiled in Canada, by Lorena Gale. canlit.ca. 
Canadian Literature, December 8, 2011. Accessed on March 14, 2014. http://canlit.ca/reviews/ memory_and_resistance

Javorčíková, Jana (2005) “'Smiling Discrimination' in Canadian Society”. The Central European Journal of Canadian Studies 5, 123-131.

Kilbourn, William (1989) “The Peaceable Kingdom Still”. In: Graubard, Stephen F. (ed.) In Search of Canada. New Brunswick: Transaction Publishers, 1-29.

Lacko, Ivan (2011) "Prečo l'udia potrebujú rozprávat' svoje príbehy. Divadelná hra The Guys od Anne Nelsonovej”. OS 4 (November 30, 2011), 193-196.

Lacko, Ivan (2013) "Tracey Scott Wilson's Buzzer and the Myth of Post-racial America". American \& British Studies Annual 6, 37-46.

McLaughlin, Cahal (2010) Recording Memories from Political Violence: A Film-Maker's Journey. Bristol: Intellect Ltd.

"Money and the ethnic votes". Wikipedia: The Free Encyclopedia. Wikimedia Foundation, Inc. Accessed on March 10, 2014.http://en.wikipedia.org/ wiki/Money_and_ethnic_votes

Morrow, Martin (1999) "Actress-Playwright Explores Pain of Minorities in Quebec". Calgary Herald, January 7, 1999. Accessed on September 15, 2014. ProQuest.

Mukherjee, Arun Prabha (1999) "Canadian Nationalism, Canadian Literature and Racial Minority Women". In: Aziz, Nurjehan (ed.) Floating the Borders: New Contexts in Canadian Criticism. Toronto: TSAR, 151-172.

Petropolous, Jacqueline (2008) “'The Ground on Which I Stand': Rewriting History, African Canadian Style”. In: Maufort, Marc and Caroline De Wagter (eds.) Signatures of the Past: Cultural Memory in Contemporary Anglophone North American Drama. Peter Lang, 73-81.

Roof, Judith and Robyn Wiegman, eds. (1995) Who Can Speak? Authority and Critical Identity. University of Illinois Press.

Ruti, Mari (2014) "Is Autonomy Unethical? Trauma and the Politics of Responsibility". In: O'Loughlin, Michael (ed.) The Ethics of Remembering and the Consequences of Forgetting: Essays on Trauma, History, and Memory. London: Rowman \& Littlefield, 37-54.

Sanders, Leslie (2003) "History at Negro Creek; Djanet Sears's The Adventures of a Black Girl in Search of God". In: Sears, Djanet (2003) The Adventures of a Black Girl in Search of God. Toronto: Playwrights Canada Press, 119-122.

Sears, Djanet (2003) The Adventures of a Black Girl in Search of God. Toronto: Playwrights Canada Press.

Shaw, George Bernard (2007) The Adventures of the Black Girl in Her Search for God. Hesperus Press. First published in 1932.

Lucia Otrísalová is Assistant Professor at the Department of English and American Studies at Comenius University in Bratislava, Slovakia, where she teaches Canadian Studies and American Literature. Her doctoral thesis was on the concepts of home and language in Caribbean-Canadian literature. Her research continues to focus on black Canadian writing and history and Canadian transcultural literature. She has also conducted research on the reception of Canadian literature in Slovakia.

Address: Lucia Otrísalová, Department of English and American Studies, Faculty of Arts, Comenius University, Gondova 2, 81499 Bratislava, Slovak Republic. [otrisalova@fphil.uniba.sk] 
